\title{
Christianity and Inequality in the Modern United States
}

\author{
Heath W. Carter
}

We are living through what many experts are calling a new Gilded Age, an era that is nothing short of historic when it comes to inequality. ${ }^{1}$ Its contours can be measured in a variety of ways. Consider, for example, that in 1973 the top $1 \%$ of American earners boasted just $9.2 \%$ of all income. Today they command fully $21 \%$. One has to go all the way back to the late 1920s, just prior to the Great Depression, to find comparable numbers. ${ }^{2}$ But the nation's wealth gap is arguably even more striking. An Institute for Policy Studies report found that, as of 2017, "the

${ }^{1}$ See, for example, Paul Krugman, "Why We're in a New Gilded Age," The New York Times, 2014, available via https://www.nybooks.com/articles/2014/05/08/ thomas-piketty-new-gilded-age/ (accessed 7 August 2018); and Eric Posner and Glen Weyl, "The Real Villain Behind Our New Gilded Age," The New York Times, 2018, available via https://www.nytimes.com/2018/05/01/opinion/monopoly-power-new-gildedage.html (accessed 7 August 2018).

${ }^{2}$ See Estelle Sommeiller and Mark Price, "The New Gilded Age: Income Inequality in the U.S. by State, Metropolitan Area, and County," Economic Policy Institute, 2018, available via https://www.epi.org/files/pdf/147963.pdf (accessed 7 August 2018).

H. W. Carter $(\bowtie)$

Princeton Theological Seminary, Princeton, NJ, USA

(C) The Author(s) 2020

T. Akram and S. Rashid (eds.), Faith, Finance, and Economy, https://doi.org/10.1007/978-3-030-38784-6_8 
three wealthiest Americans-Bill Gates, Jeff Bezos, and Warren Buffettowned more wealth than the entire bottom half of the American population combined, a total of 160 million people or 63 million households." 3 One common response to such statistics is to stress their relativity: sure, there may be a widening gap between rich and poor in the United States, but even the poor here are rich by global standards. But this perspective may lead some to underestimate the existence of real-and in some cases, outright lethal—suffering right here in the land of plenty. In Chicago, life expectancy varies by more than 15 years depending on one's census tract, with a range extending from 83.3 years on the Near North Side (where household incomes exceed $\$ 77,000$ per year) to just 68.2 years in West Garfield Park (where household income is just under $\$ 24,000$ per year). ${ }^{4}$ Between the extremes, wage stagnation is pervasive, with middle-income workers' real wages increasing only $0.2 \%$ per year over the last forty years, even as low-wage workers have seen a $5 \%$ decline in their real wages over the same period. ${ }^{5}$

Whatever the similarities between the days of Carnegie, Rockefeller, and Vanderbilt and our own, there remains this fundamental difference: late nineteenth-century Christians were less inclined to give inequality their "amen." In the face of the original Gilded Age's notorious disparities, ordinary believers built a variety of movements challenging the deep structures of industrial capitalism, contributing in the process to an unprecedented, nationwide ferment regarding the shape of a moral economy. On this particular front the analogy to our time breaks down. After all, the contemporary social movement most often identified with these issues, Occupy Wall Street, enjoyed tepid support, at best, from the nation's churches, which is perhaps partly why it proved such a flash in the pan. It left only a rhetorical flourish (the $1 \%$ vs. the $99 \%$ ) in its wake-one

${ }^{3}$ Chuck Collins and Josh Hoxie, "Billionaire Bonanza: The Forbes 400 and the Rest of Us," Institute for Policy Studies, 2017, available via https://ips-dc.org/ wp-content/uploads/2017/11/BILLIONAIRE-BONANZA-2017-FinalV.pdf (accessed 7 August 2018).

${ }^{4}$ Bijou R. Hunt, Gary Tran, and Steve Whitman, "Life Expectancy Varies in Local Communities in Chicago: Racial and Spatial Disparities and Correlates," Journal of Racial and Ethnic Health Disparities 2, no. 4 (December 2015): 425-433.

${ }^{5}$ Lawrence Mishel, Elise Gould, and Josh Bivens, "Wage Stagnation in Nine Charts," Economic Policy Institute, 6 January 2015, available via https://www.epi.org/files/ 2013/wage-stagnation-in-nine-charts.pdf (accessed 7 August 2018). 
that has failed to brighten the prospects of the labor movement, which today enrolls only $6.5 \%$ of private sector workers. ${ }^{6}$

Spiraling inequality has many sources, of course, but in this essay I will explore its spiritual roots. Historians of American Christianity have often taken denominational and/or theological conflict as a central plotline, crafting stories about rivalries between Baptists and Methodists, Protestants and Catholics, fundamentalists and modernists, and so on. ${ }^{7}$ These stories are certainly revealing in their own right. But they often conceal another central fault line in the history of modern American Christianity, one that cuts straight through denominations and across theological camps: namely, the moral status of inequality. For more than one hundred and fifty years American Christians have been deeply divided about not just the sources of inequality-whether it derives first and foremost from individual failings or from social structures-but also about whether faithful believers are obligated to join the fight against it. In this chapter I will offer a brief overview of these battles from the first Gilded Age to our own, tracing them through four distinct phases of development. It will become clear that this struggle has often involved a tug-of-war between church leaders and believers at the grassroots, with all parties well aware that struggles over the meaning of Christianity for the modern world have major implications not only for the churches but also for the soul of the nation.

This chapter may also be read as a concise introduction to the history of social Christianity, a heterogeneous tradition which arose from the grassroots in the nineteenth century and which reached the apex of its influence in the mid-twentieth century. This tradition has at its core several distinctive intuitions: (1) that inequality is sinful; (2) that the source of inequality is, first and foremost, not within the individual but without, in the systems and structures of society; and therefore; and (3) that Christian faith requires participation in fights for the reform and reconstruction of unjust systems. Over the course of the hundred years stretching form

6 "Union Members Summary," Bureau of Labor Statistics, 19 January 2018, available via https://www.bls.gov/news.release/pdf/union2.pdf (accessed 7 August 2018).

${ }^{7}$ This is especially characteristic of the grand narrative tradition pioneered by Robert Baird, whose landmark 1844 book, Religion in America, or, An account of the origin, progress, relation to the state, and present condition of the evangelical churches in the United States: with notices of the unevangelical denominations divvied the nation's churches into "evangelical" and "unevangelical" camps. 
the end of the Civil War to the apex of the modern Civil Rights Movement, a vast and diverse array of social Christians sought to vanquish American inequality. They came as close as anyone ever has. Only when they began to falter in the face of mighty headwinds did our new Gilded Age come into view.

\section{Phase One: Grassroots Uprisings, i865-i900}

The late nineteenth century was an age of stark contrasts: in the experiences of rich and poor, to be sure, but also in the reactions of the institutional churches and everyday Christians to the jaw-dropping inequality in their midst. Across denominations, throughout these postbellum decades, the clergy largely failed to champion structural solutions. The American Catholic hierarchy proceeded cautiously in all social and political affairs. While the Church's numbers were growing exponentially, its position in a broader society long prone to fits of anti-immigrant and anti-Catholic sentiment remained tenuous. Priests, bishops, and especially nuns, poured their resources into charitable endeavors during these years in a heroic attempt to meet the needs of the faithful without causing too much of a stir. ${ }^{8}$ Meanwhile, their Protestant counterparts, who retained significant cultural authority even in the wake of the theological crisis that was the Civil War, tended to champion a classical liberalism that attributed widespread poverty to the sins of the poor. ${ }^{9}$

Take, for example, the case of the Reverend David Swing, a nationally renowned Presbyterian minister who is best remembered in American religious history for his pathbreaking theological liberalism. ${ }^{10}$ In the early 1870s he was run out of the Presbyterian Church for his low view of biblical authority and reinterpretation of historic Christian doctrines. But during those same years, amid the rise of the modern labor movement,

\footnotetext{
${ }^{8}$ On the centrality of nuns in particular, see Suellen Hoy, Good Hearts: Catholic Sisters in Chicago's Past (Urbana: University of Illinois Press, 2006); and Maureen Fitzgerald, Habits of Compassion: Irish Catholic Nuns and the Origins of New York's Welfare System (Urbana: University of Illinois Press, 2006).

${ }^{9}$ For more on the damage the Civil War wreaked on Protestant America, see Mark A. Noll, The Civil War as a Theological Crisis (Chapel Hill: University of North Carolina Press, 2006).

${ }^{10}$ See, for example, William R. Hutchison, The Modernist Impulse in American Protestantism (Durham: Duke University Press, 1976).
} 
Swing made a name for himself as a staunch defender of laissez faire economics. In 1874, amid one particularly severe economic downturn, Swing declared in no uncertain terms, "The conflict between classes in the cities of our country is not a conflict between labor and capital, but between successful and unsuccessful lives." In contrast with feudal Europe, the United State was, in Swing's estimation, a land of opportunity, one in which the poor were without excuse. He went on:

The reason is the man who raves about the relief fund is not in as easy circumstances as, for example, George Armour, is because he did not come here thirty years ago, and heave trunks at a hotel and invest each ten dollars in a town lot. The reason why Mr. Hoffman's poor man is not wealthy as Wirt Dexter is because he did not go to a country school as Dexter did, and then bend down to twenty years of bondage at the law, studying cases far into the night.

Holding fast to an important vein of antebellum conventional wisdom, Swing went on to insist, "In our crisis the lesson taught the people should not be that labor and capital are enemies, but that capital in this country is labor. The rich man of today was the laborer of yesterday, and before the poor man of today there lies the hope of a better future... [which will come] by the old way of economy and industry and intelligence." 11

Countless ordinary believers begged to differ. During these same late nineteenth-century decades a variety of faith-infused movements against inequality sprung up at the grassroots. At least four deserve some mention here. First, workers banded together in unions and labor federations, which were also hotbeds of dissenting Christian theologies. ${ }^{12}$ Union leaders such as Andrew Cameron fought not only for shorter hours and higher wages, but also against the dominant strains of Christian economic thought. Cameron, the editor of the nation's most important labor paper throughout the 1860s and 1870s, wrote in one issue, "It is a startling fact that the modern pulpit has arrayed itself on the side of the oppressor; has almost invariably defended the aggressions of the monied power; and used its high and holy mission to pervert the ways of the Lord."13

${ }^{11}$ David Swing, "The Labor Turmoil," Alliance 1, no. 4 (3 January 1874): 2.

${ }^{12}$ See Heath W. Carter, Union Made: Working People and the Rise of Social Christianity in Chicago (New York: Oxford University Press, 2015).

13 “Rev. Dr. Westwood," Workingman's Advocate 5, no. 27 (30 January 1869): 2. 
As harsh as these words were, they did not proceed from the pen of an embittered outsider. Cameron was himself a believing Christian. While cognizant of widespread associations between working-class protest and godlessness, he denied any necessary link between the two. He declared in one editorial, "Our fight is not against Christianity, but against those who use it as a cloak to secure their selfish purposes," and in another that "the Gospel of Christ sustains [labor] in our every demand...the volume of Divine inspiration is the rock of truth upon which our 'pretensions' are founded."14

Women often found themselves on the outside looking in at the early labor movement, but as they gained ground within unions at the turn of the century, they too mounted arguments regarding the Christian basis of their activism. Agnes Nestor, a devout Catholic and leading figure within the Women's Trade Union League, took advantage of every available opportunity to implore middle-class Christian audiences to join working women's fight. To one particularly affluent congregation in Chicago's northern suburbs she declared, "You are so far removed from the life of the factory girl that you cannot understand the view she takes of life." In Nestor's view, this distance represented a shirking of Christian duty. She went on, "It is the work of the church to take an active instead of passive interest in the welfare of the mothers of to-morrow and lend its strength toward a betterment of conditions. $" 15$

A second grassroots movement sought to generate bonds of solidarity and ameliorate abhorrent conditions in the nation's industrializing "shock cities." With leading clergy largely paralyzed by the emergence of sprawling communities of working-class immigrants in their midst, middle-class women-who were themselves barred from the ministrytook the lead in forging connections. Reformers such as Mary McDowell and Jane Addams founded settlement houses in the poorest and most environmentally degraded urban neighborhoods, eager to live out Jesus's command to love one's neighbor as oneself. These houses soon became hubs of community activism, where residents organized to fight for everything from public baths, parks, and playgrounds to labor rights and women's suffrage. McDowell had come of age in Evanston, Illinois-a center

14 "Christianity a Failure," Workingman's Advocate 4, no. 42 (9 May 1868): 2; and “Liberal Christianity," Workingman's Advocate 4, no. 17 (16 November 1867): 2.

15 "In Factory Girl Plea; Piecework Is Scored," Chicago Record-Herald, 5 September 1910. 
for energetic Methodist reform, thanks in large part to the presence of the Women's Christian Temperance Union-and a strong Christian idealism animated her four decades in Chicago's stockyards district. Musing as to why more believers did not jump so readily into the urban fray, she reflected, "I sometimes have wondered whether or not Christians have a consciousness of a present Christ - a God in the flesh - a 'contemporary,' who is with us in all our crudeness. Must I not see Him here back-ofthe-Stockyards - a living presence making the struggle of the individual as well as of the group a sacred and holy thing?" $16 \mathrm{McD}$ Dowell was hardly alone among settlement house workers in sensing the nearness of Christ in poor neighborhoods. Addams traced their movement's roots to "a certain renaissance going forward in Christianity. The impulse to share the lives of the poor, the desire to make social service, irrespective of propaganda, express the spirit of Christ, is as old as Christianity itself." She went on to say, "I believe that there is a distinct turning among some young men and women toward this simple acceptance of Christ's message. They resent the assumption that Christianity is a set of ideas which belong to the religious consciousness, whatever that may be. They insist that it cannot be proclaimed and instituted apart from the social life of the community and that it must seek a simple and natural expression in the social organism itself." 17

On the other side of the Mason-Dixon line, meanwhile, a third grassroots movement took shape, as black freedom fighters sought to reconstruct the postbellum South on a racially egalitarian democratic basis. Black activists founded local chapters of the Union League and Republican Party across the region, while also establishing independent black churches at a remarkable clip. These fledgling institutions, whose very existence was a protest against the southern status quo ante, struggled just to survive amid the white paramilitary counterinsurgency of the early 1870s and so it's little surprise that black churches were not uniformly committed to activism as a central outworking of Christian faith. ${ }^{18}$ But

${ }^{16}$ Undated letter to Shailer Mathews, Mary McDowell Settlement records, Box 4, Folder 21, Chicago History Museum, Chicago, IL.

${ }^{17}$ Jane Addams, "The Subjective Necessity for Social Settlements," in Philanthropy and Social Progress (New York: Thomas Y. Crowell, 1893).

${ }^{18}$ See Steven Hahn, A Nation Under Our Feet: Black Political Struggles in the Rural South from Slavery to the Great Migration (Boston: Harvard University Press, 2003). 
a variety of streams of black Christian protest emerged despite imminent threats to life and limb. There was a black nationalist incarnation, embodied by African Methodist Episcopal (AME) bishop Henry McNeal Turner, who already in the late nineteenth century was arguing "God is a Negro." A second stream reflected the philosophy of Booker T. Washington, whose message of incremental racial uplift through economic development included an emphasis on the ethical dimensions of Christianity. His most formidable rival was W. E. B. Du Bois, who advanced a vision of a radical Jesus from outside the confines of the institutional church and who helped to inspire other black social Christians. Like Du Bois, Ida B. Wells rejected Washington' strategy in favor of a more radical politics, even as she poured her energies into a courageous and peripatetic anti-lynching campaign. Meanwhile, figures such as Nannie Burroughs and Adam Clayton Powell, Sr., mediated between Washington and Du Bois, modeling an approach that fused their best insights. Collectively, their struggle against a heinous Jim Crow order would prepare the way for civil rights activists to come. ${ }^{19}$

Finally, in parts of both the South and West, farmers joined together, sometimes even across racial lines, to power a fourth set of grassroots movements challenging the power of the nation's ruling elite. From the Grange and the Farmers' Alliance to the People's Party, their organizations were suffused with Christian ideas and powered by Christian activists who mounted a fierce assault on the monied powers of Wall Street. Expressing a "righteous indignation" at the ways that a complacent "churchianity" underwrote elite rule, they threw their weight behind a Populist movement that briefly gained national prominence in the early 1890s before flaming out and taking with it hopes for a progressive biracial political coalition. ${ }^{20}$ Their concerns found an enduring advocate in the person of William Jennings Bryan, an evangelical Christian and threetime presidential candidate, who declared in a legendary 1896 speech at the Democratic National Convention, "we shall answer their demands for a gold standard by saying to them, you shall not press down upon the

${ }^{19}$ Gary Dorrien, The New Abolition: W. E. B. Du Bois and the Black Social Gospel (New Haven: Yale University Press, 2015).

${ }^{20}$ Joe Creech, Righteous Indignation: Religion and the Populist Revolution (Urbana: University of Illinois Press, 2006). 
brow of labor this crown of thorns. You shall not crucify mankind upon a cross of gold." 21

\section{Phase Two: Institutional Breakthroughs, i900-I935}

By the early twentieth century, the nation's sundry industrial crises and the intentional pressure exerted by these grassroots movements had generated a serious crisis for the leaders of the nation's Christian institutions: if they did not embrace a more egalitarian gospel-and fast-it appeared they might soon forfeit their credibility with ordinary people. Venerable dreams of "Christian America" seemed suddenly imperiled. These anxieties empowered scattered reformers on the inside, who systematized and popularized social Christian ideas, hoping to capture the hearts of their fellow middle-class Christians.

The best known was Walter Rauschenbusch, who had gotten his start as a pastor in New York City's hardscrabble Hell's Kitchen neighborhood and whose 1907 book Christianity and the Social Crisis went on to become an immediate sensation, selling more than 50,000 copies. ${ }^{22}$ Drawing on modern biblical scholarship but also infused with evangelical zeal, the book located Jesus in the prophetic tradition of the Hebrew scriptures and argued that the late antique church's embrace of wealth and empire had been a conspicuous betrayal of its founder. Rauschenbusch insisted that it was not too late to right the course, but that it would require a fundamental recommitment to Christianity's "essential purpose": "to transform human society into the kingdom of God by regenerating all human relations and reconstituting them in accordance with the will of God." 23 The book resonated with white middle-class Protestant audiences precisely because it seemed to illumine a way forward through the crises which the Christian activists of the Gilded Age had intentionally brought to a head. It proved a source of particular encouragement to the many who were distressed about ordinary believers' growing disaffection from the churches. A Baptist minister in Concord, New

${ }^{21}$ Michael Kazin, A Godly Hero: The Life of William Jennings Bryan (New York: Anchor Books, 2006).

${ }^{22}$ Christopher H. Evans, The Kingdom Is Always but Coming: A Life of Walter Rauschenbusch (Grand Rapids: William B. Eerdmans Publishing Company, 2004).

${ }^{23}$ Walter Rauschenbusch, Christianity and the Social Crisis (New York: Macmillan, 1907), xiii. 
Hampshire, penned a letter in the winter of 1908 relaying that he had read the book the year before "and ever since it has been working in my mind." He had spent the months immediately prior "trying to do something to arouse my church to the situation and to get into touch with the labor union men in Concord." His sermon on "The Church and the Labor Question" had in fact produced a relational breakthrough with the workers organized through that city's Central Labor Union, giving him hope for the future of the American churches: "If they are ready in conservative, aristocratic old Concord, they are almost anywhere," he reflected. ${ }^{24}$

They were, indeed, ready elsewhere. These were the decades when social gospels gained a significant institutional foothold. Nearly every denomination created boards and committees to consider and coordinate responses to a vast range of social problems, ranging from child labor and prostitution to temperance and race relations. In 1903 alone the Presbyterian Church founded a Department of Church and Labor, and the Congregational and Episcopal Churches established commissions to investigate industrial problems. The Methodists established a Federation for Social Service in 1907 and soon thereafter endorsed a "Social Creed" that called "For the principle of conciliation and arbitration in industrial dissensions," "For a living wage in every industry," and "For such regulation of the conditions of labor for women as shall safeguard the physical and moral health of the community." The following year the fledgling Federal Council of Churches (FCC) — which would develop into a powerful vehicle for Protestant collaboration on social problems ratified that creed. Just over a decade later Roman Catholics established their own hub for cooperation in the National Catholic Welfare Conference (NCWC). For years to come its leaders, including notable figures such as Father John Ryan and Dominican Sister Vincent Ferrer, would devote themselves to bringing a tradition of modern Catholic economic teaching, inaugurated by the Gilded Age encyclical Rerum Novarum, to the masses. ${ }^{25}$

${ }^{24}$ Virgil V. Johnson to Walter Rauschenbusch, 11 December 1908, Box 25, Folder 3, Walter Rauschenbusch Papers, American Baptist Historical Society, Atlanta, GA.

${ }^{25}$ See Carter, Union Made, 150-182. 
During these pivotal early twentieth-century decades social Christians moreover attained greater clout within local, state, and national governments, helping to promote certain kinds of egalitarian reforms. From Samuel M. "Golden Rule" Jones, the mayor of Toledo, Ohio, from 18971899 to J. Stitt Wilson, the Christian socialist mayor of Berkeley, California, from 1911 to 1913 , they made major contributions to municipal reform. Others such as Norman Thomas sought political office but never attained it. A graduate of Union Theological Seminary, where he read Rauschenbusch and more, Thomas ran for governor of New York in 1924, mayor of New York City in 1925 and 1929, and then for president of the United States as a socialist candidate on six different occasions. He proved influential despite his penchant for losing, about which he had a good sense of humor: "I am not the champion of lost causes, but the champion of causes not yet won," he liked to say. ${ }^{26}$

The New Deal was among the clearest of causes won for Christians devoted to the fight against inequality. The unprecedented avalanche of legislation signed by President Franklin D. Roosevelt in his first hundred days alone created a larger and more interventionist federal government than the nation had ever known. Many members of the Cabinet were steeped in social Christianity, including Frances Perkins, who as Secretary of Labor from 1933 to 1945 was one of the welfare state's foremost architects. As her biographer, George Martin, writes, "What Perkins chose to do was determined by her religion. Many Democrats supported the Social Security Act because it attracted votes; others, for humanitarian reasons; Perkins, 'for Jesus' sake,' because it brought the City of God closer to the cities of toil and industry." 27 Her colleague, Secretary of the Interior Harold Ickes, made these connections explicit when he addressed the leaders of the Presbyterian Church USA in the spring of 1934. "Christ wanted men and women to live upright lives," Ickes acknowledged, "but he also wanted them to have for each other understanding and good will and mutual helpfulness. He wished them to be good neighbors. He hated

\footnotetext{
${ }^{26}$ Robert Hyfler, Prophets of the Left: American Socialist Thought in the Twentieth Century (Westport, CT: Greenwood Press, 1984).

${ }^{27}$ George Martin, Madam Secretary, Frances Perkins (Boston: Houghton Mifflin Company, 1976), vii.
} 
injustice with a righteous hatred. His whole life was a fight against oppression." 28 In Ickes's estimation the New Deal reflected not just the principles of the Golden Rule but the social vision of the savior himself. He closed the speech with the confident declaration, "If our civilization is to advance, if we are to establish on this earth the social state envisaged by the Founder of Christianity, the citadel of entrenched privilege must be carried, and in due course, by the grace of God, it will be carried." 29 This view resonated at the grassroots-perhaps never before had the immorality of economic inequality seemed so intuitive to so many people-but it also inspired a backlash in high places. More on that below, but for the time being, suffice it to say that by the late-1930s, social Christianity's influence over both church and state was receding in the face of concerted political and theological resistance. Its future would rest once more in the hands of ordinary believers on the ground.

\section{Phase Three: On the March, I935-I975}

During the years stretching from roughly 1935 to 1975 ordinary Christians committed to a more egalitarian society fundamentally changed the nation. Throughout the late 1930s everyday believers poured into the Congress of Industrial Organizations, which organized workers across lines of race and gender, constructing the kind of formidable big tent union that had so long proved elusive. Meanwhile, a Catholic Worker movement founded in New York City by Dorothy Day and Peter Maurin quietly gained momentum. Day was deeply influenced by the tradition of Catholic social teaching that had emerged in the Gilded Age and Progressive Era. But unlike many of her fellow believers, she doubted that social salvation would be achieved through New Deal-style bureaucracies. Later in life she reflected, "Young people say, What good can one person do? What is the sense of our small effort? They cannot see that we must lay one brick at a time, take one step at a time, we can be responsible only for the action of the present moment. But we can beg for an increase

\footnotetext{
28 "New Deal Is Based on Christ's Tenets, Ickes Says in Talk," Chicago Daily Tribune, 24 May 1934.

${ }^{29}$ Department of the Interior Memorandum for the Press, Address by Honorable Harold L. Ickes, Secretary of the Interior, at meeting of Presbyterian General Assembly, 24 May 1934, Folder 63a, Harold L. Ickes Papers, Library of Congress, Washington, DC.
} 
of love in our hearts that will vitalize and transform all of our actions, and know that God will take them and multiply them, as Jesus multiplied the loaves and the fishes." ${ }^{30}$ While many doubted the effectiveness of Day's incarnational approach, it caught on well beyond New York City. Catholic Workers houses sprouted up across the country and out of them grew many other movements as well, including one which became a force in 1940s Detroit.

Home to Walter Reuther and the powerful United Automobile Workers (UAW) union, World War II-era Motor City was also the place where arguably the most influential chapter of the Association of Catholic Trade Unionists (ACTU) took shape. The organization infused Detroit's union locals with a progressive Catholic spirit. One chapter affiliated with Chrysler UAW Local 7 declared in its newspaper, "WE, AS CATHOLICS, HAVE A SPECIAL RESPONSIBILITY TO SEE THAT OUR UNIONS ARE EFFECTIVE, MILITANT, AND RUN PROPERLY." 31 1940s Detroit served also as a headquarters for Claude Williams' People's Institute of Applied Religion. Williams had imbibed the social Christian radicalism of southern churchman Alva Taylor and now sought to bring it to bear on the racism and classism that structured life in mid-century Detroit. He took his egalitarian message directly to the shop floors, even as he galvanized a variety of new initiatives involving also church youth groups and everyday ministers. ${ }^{32}$ What was happening in Detroit was connected to developments in other industrial cities as well. In Chicago Bishop Sheil had forged close relationships with leaders in the Congress of Industrial Organizations and in Washington, DC the National Catholic Welfare Conference was sponsoring summer schools for women workers.

Even as the labor movement gained steam in the postwar United States, so did a massive, faith-infused civil rights movement. The breakthroughs of the 1950s and 1960s did not come out of nowhere. Activists built on organizing traditions cultivated over the course of generations.

${ }^{30}$ Dorothy Day, Loaves and Fishes: The Inspiring Story of the Catholic Worker Movement (New York: Orbis Books, 1997).

${ }^{31}$ Matthew Pehl, The Making of Working-Class Religion (Urbana: University of Illinois Press, 2016).

${ }^{32}$ Erik S. Gellman and Jarod Roll, The Gospel of the Working Class: Labor's Southern Prophets in New Deal America (Urbana: University of Illinois Press, 2011). 
The movement was religiously and racially diverse, but at its very center were black Christians whose gospel was intuitively egalitarian. Mississippi activist Fannie Lou Hamer did not need to read Walter Rauschenbusch or W. E. B. Du Bois to know that God longed for her people to be free. But the movement's most influential spokesperson, the Reverend Martin Luther King, Jr., had read both of them and many more besides. King's speeches moved seamlessly between the biblical prophetic tradition and the nation's republican ideals, and brought both to bear on the systemic injustice of the contemporary American scene. The everyday activists who showed up for rallies and bore the brunt of the often brutal opposition were the guarantors of his leverage with high-level negotiators, who were in turn often anxious, especially given the Cold War context, to avoid appearing undemocratic. As mass meetings, marches, boycotts, sit-ins, and speeches parlayed into historic breakthroughs in the form of court decisions and federal legislation, social Christians collaborated with numerous others to leave arguably their most lasting mark on American society. ${ }^{33}$

Before all was said and done, what began in Detroit and Montgomery would reverberate all the way to California, where in the 1960s and 1970s Dolores Huerta and Cesar Chavez mobilized a movement of Latino and Filipino workers that brought the state's mightiest growers to the bargaining table. Marching workers carried images of the Virgin of Guadalupe and framed their protests as pilgrimages. Chavez himself had been deeply influenced by a Catholic priest who introduced him to the church's social teaching, among other things. In his 1966 Plan of Delano he hearkened back to the Gilded Age encyclical Rerum Novarum, declaring, "All men are brothers, sons of the same God; that is why we say to all men of good will, in the words of Pope Leo XIII, 'Everyone's first duty is to protect the workers from the greed of spectators? who use human beings as instruments to provide themselves with money. It is neither just nor human to oppress men with excessive work to the point where their minds become enfeebled and their bodies worn out." Thanks in no small part to the

${ }^{33}$ See David L. Chappell, A Stone of Hope: Prophetic Religion and the Death of Jim Crow (Raleigh, NC: University of North Carolina Press, 2005); Mary L. Dudziak, Cold War Civil Rights: Race and the Image of American Democracy (Princeton: Princeton University Press, 2000); and Taylor Branch's prize-winning trilogy on America in the King Years. 
tenacity of the farm workers themselves, by the early 1970s the movement had successfully organized much of the industry. ${ }^{34}$ A Social Christian tradition that had arisen at the grassroots now ushered the nation to the cusp of the mountaintop-only to fall back down.

\section{Phase Four: Toward a New Gilded Age}

How did the United States fall from that mountaintop to an age of nearly unprecedented inequality? It's a complex and multi-faceted story, but major shifts in the American Christian landscape help to explain current trends. The story extends at least back to the 1930s. From very early in FDR's administration the heads of the National Association of Manufacturers cultivated relationships with Christian clergymen like James Fifield, a theologically liberal and economically libertarian Congregationalist based out of Los Angeles. Fifield founded an organization called Spiritual Mobilization, which sought to defeat the New Deal by rallying clergy and ordinary believers alike to the gospel of free enterprise. Whereas many social Christians found in the Bible a plain justification for redistributionist programs, Fifield and others of his ilk argued that the free market way was not only the American way but also God's. ${ }^{35}$ They set out to dismantle the social gospel institutions that had been so painstakingly constructed earlier in the twentieth century.

By the early 1950s, for example, Fifield was coordinating a frontal assault on the Congregationalist Church's Council for Social Action. He sent letters to leading churchmen, which stated, "Some of us have become very much concerned about the Council for Social Action of our Congregational Denomination. Our Methodist friends tossed that group out of their General Conference a year or so ago." He went on to explain, "It certainly does not act for me and I am sure not for you and most Congregationalists - yet it maintains a registered lobbying office in Washington, and presumes to speak on many issues which are of vital importance in

${ }^{34}$ Luis D. Leon, The Political Spirituality of Cesar Chavez: Crossing Religious Borders (Oakland: University of California Press, 2014).

${ }^{35}$ See Kevin Kruse, One Nation Under God: How Corporate America Invented Christian America (New York: Basic Books, 2015); and Darren Dochuk, From Bible Belt to Sunbelt: Plain-Folk Religion, Grassroots Politics, and the Rise of Evangelical Conservatism (New York: W. W. Norton, 2011). 
relation to National and world trends." 36 When the head of the Council confronted Fifield about the discord he was sowing, he responded matter-of-factly, "my personal feeling about the Council for Social Action is exactly as it has been through the years and as I explained to you last time we talked; namely, that we should not have a Council for Social Action, that the net end result has been a liability rather than an asset."37

The campaign was hardly limited to California. The chair of one allied group, The Committee Opposing Congregational Political Action, was based in Minneapolis; its board included members from Connecticut, New York, Michigan, Illinois, and more. That group distributed a booklet with the ominous title "They're Using Our Church..." When one turned the page, the words TO PLAY POLITICS! appeared in capitalized and emboldened text. The authors went on to accuse the Council of favoring "socialized medicine," of having personal connections to "Communist Fronts," and of being soft on Russia and China. The booklet closed with an action plan for the reader to pursue and a choice quote from Abraham Lincoln: “...With Firmness In The Right, As God Gives Us To See The Right." 38 The coordinated effort proved highly effective. As one Congregationalist pastor went on to report to the Council for Social Action's leadership, "the CSA, as presently organized, is 'discredited' among many." 39 Christian libertarian crusaders such as Fifield did not struggle to find major boosters in both the philanthropic and corporate worlds. Groups such as Spiritual Mobilization struggled initially to gain traction at the grassroots but a number of larger factors and forces would work together, over time, to yield a new harvest of ordinary Christian converts to the gospel of free enterprise.

One such factor was the Cold War. Over the course of the nation's standoff with the Communist and atheistic Soviet Union it would come to seem to more and more believers that Christianity, free enterprise, and American patriotism were a match made in heaven. The specter of

\footnotetext{
${ }^{36}$ James W. Fifield, Jr., to Mr. W. H. Danforth, 24 September 1951, Box 1, Folder BR 5, Council for Social Action Papers, Congregational Library, Boston, MA.

${ }^{37}$ James W. Fifield, Jr., to Dr. Ray Gibbons, 1 November 1951, Box 1, Folder BR 5, Council for Social Action Papers, Congregational Library, Boston, MA.

38 “They're Using Our Church..." Booklet, Box 1, Folder BR 2, Council for Social Action Papers, Congregational Library, Boston, MA.

${ }^{39}$ Henry David Gray to Liston Pope, 13 June 1953, Box 1, Folder BR 5, Council for Social Action Papers, Congregational Library, Boston, MA.
} 
violent totalitarian regimes was raised to defeat even modest calls for economic redistribution and social welfare programs. Christian socialism, which had enjoyed a significant following of working-and-middle-class believers throughout the late nineteenth and early twentieth centuries, became not just taboo but in fact grounds for investigation and blacklisting. Meanwhile, savvy entrepreneurs such as Sam Walton, the founder of Wal-Mart, would capitalize on the opportunities the early Cold War revival presented, enveloping hard-nosed labor and supply chain practices in a service ethos and faith-and-family-friendly brand that resonated first across the Bible Belt and before long the entire land. For countless employees and customers alike, serving God and serving companies like Wal-Mart came to seem almost of a piece. ${ }^{40}$

Another key factor in the rise of grassroots conservatism was the white response to the Civil Rights movement. The resistance included an explicitly racist wing, which enjoyed strong support not only in the South but also in Northern cities where white residents, outraged by open housing laws, often turned viciously on black neighbors. This movement, whose figurehead was the arch-segregationist George Wallace, inflicted great damage, but its long-term impact paled in comparison to that of an emerging white "silent majority" whose unrelenting faith in meritocracy eroded support for structural approaches to addressing inequality. Its strongholds were the Sunbelt suburbs, which were also increasingly the nation's demographic center of gravity. The silent majority rejected New Deal-style programs in favor of colorblind, laissez faire policies, which contradicted many a denomination's social teaching, but which dovetailed seamlessly with the doctrines of a surging Christian libertarianism. ${ }^{41}$ This tension between official church positions and the faithful's economic outlook was not always apparent in local churches and parishes, far removed as they were from denominational headquarters. And with the 1980s emergence of a hard-charging Religious Right-which saw a role for the state in controlling individual behavior, but not in promoting distributive justice - any remaining whiff of tension between Christian convictions and neo-liberal economics evaporated for countless white Protestants and Catholics alike.

\footnotetext{
${ }^{40}$ Bethany Moreton, To Serve God and Wal-Mart: The Making of Christian Free Enterprise (Boston: Harvard University Press, 2009).

${ }^{41}$ Matthew D. Lassiter, The Silent Majority: Suburban Politics in the Sunbelt South (Princeton: Princeton University Press, 2006).
} 
Other key factors took shape far from the realm of formal politics. Throughout the twentieth century's final decades, millions of ordinary believers joined churches which taught that prosperity came not through gritty organizing efforts but rather through individual access to divine power. Drawing on a tradition in modern American life that stressed the power of positive thinking, preachers such as Houston's Joel Osteen argued, "You can change your world by changing your words." Millions more who did not attend prosperity churches still voraciously consumed therapeutic Christianities and their proliferating products: books, magazines, devotionals, music, clothing, and more, which blended faith and self-help for a generation that took pride in being spiritual but not religious. $^{42}$

Social Christianity never completely disappeared, but it was increasingly relegated to the margins of American life. Throughout the Reagan years and in the decades that followed it animated movements for nuclear disarmament and immigrant and refugee rights. Black social gospelers continued to prophesy against structural racism but their message largely failed to gain traction with a white Christian majority persuaded that the nation had addressed its original sin back in the Civil Rights era. Incontrovertible visual evidence of police brutality changed some white minds in the early twenty-first century. But in its initial phase at least, the Black Lives Matter movement succeeded more at calling attention to violations of individual rights than to the structural underpinnings of persistent racial inequality. On an even broader scale, if many ordinary believers had once seen structural inequality as a sin they were called to fight, it now came to seem almost natural and in some cases even God ordained. As older moral intuitions faded, a new refrain came into vogue: "That's just the way the market works." As that logic took hold, not just in many pulpits but also in the pews, it became clear: the dream of a more egalitarian society had flourished first at the grassroots and it withered there too.

\footnotetext{
${ }^{42}$ Kate Bowler, Blessed: A History of the American Prosperity Gospel (New York: Oxford University Press, 2013); Heather Hendershot, Shaking the World for Jesus: Media and Conservative Evangelical Culture (Chicago: The University of Chicago Press, 2004); R. Laurence Moore, Selling God: American Religion in the Marketplace of Culture (New York: Oxford University Press, 1994); and David W. Stowe, No Sympathy for the Devil: Christian Pop Music and the Transformation of American Evangelicalism (Raleigh: University of North Carolina Press, 2011).
} 
The impact is felt today across the nation. Arguably nothing so dramatically underscores the diminished status of social Christianity as the latterday collapse of the labor movement. A working paper published by several Princeton economists earlier this year underscored once more that unions remain one of the surest bulwarks against spiraling income inequality. ${ }^{43}$ Yet in the early twenty-first century-with fully seventy-seven percent of the nation's population still identifying as Christian-less than seven percent of private sector workers belong to unions. For social Christianswhose visions of justice rolling down like waters had, just a single generation before, transfixed the nation-such developments are clear evidence of a return to the wilderness.

But hope persists, even in the wilderness. Several years ago, for one long winter night, the daunting realities of our new Gilded Age seemed almost destined to be overcome. As the mass meeting got underway at Selma's Tabernacle Baptist Church, hundreds were still filing in, hoping to find a place to stand in the balcony or along the perimeter of the main sanctuary below. It was March 5, 2015, nearly fifty years to the day since the infamous "Bloody Sunday" march that had earned this otherwise unremarkable town, the seat of dirt poor Dallas County, Alabama, a place in the annals of the twentieth century. Many of the saints who powered the local movement long before Martin Luther King, Jr., ever set foot in Selma were seated in the first two rows. The choir got things off to a rousing start, but then halfway through its set a hush descended on the place. Someone was wheeling Amelia Boynton-frail now at 103 years old, but in her prime the most formidable thorn in the side of the area's white supremacist ruling class - to the front. Eyes that had not yet dried watered freely once more as the multiracial assembly belted out the lyrics of the old freedom song, "We Shall Overcome," and as NAACP President Cornell William Brooks invoked the memory of Medgar Evers, the martyred activist whose last words, as he lay bleeding, were "Sit me up! Turn me loose!" Stirring reflections from luminaries such as Jeremiah Wright and Bernice King followed, but it was the Reverend William J. Barber II who brought down the house. He began softly, even tentatively, but soon

${ }^{43}$ Henry S. Farber, Daniel Herbst, Ilyana Kuziemko, Suresh Naidu, "Unions and Inequality over the Twentieth Century: New Evidence from Survey Data" (working paper), available via https://dataspace.princeton.edu/jspui/bitstream/88435/ dsp01gx4lmm54w/3/620.pdf (accessed 8 August 2018). 
enough was thundering against contemporary manifestations of inequality, including the 2013 Supreme Court decision that had eviscerated the hard-won 1965 Voting Rights Act. Over and over Barber vowed that God's people must see this historic anniversary not as a "commemoration" but rather as a "consecration" to the work of justice and righteousness in our time. By the time he reached the climax of his address, the crowd was on its feet, applauding vigorously and shouting "Amen." The Spirit did not move like this nearly as often as it once did.

Prior to that evening in Selma, I had never heard of Barber. His is still not a household name, though his renown certainly grew when in 2016 he delivered a nationally televised address at the Democratic Convention. He earned a slot on that stage through his work galvanizing the "Moral Mondays" movement, which rallied thousands in protest of the North Carolina state legislature's sweeping tax cuts, funded in part by corresponding cuts to Medicaid and unemployment benefits. Some credit Barber's leadership with helping to unseat Republican Governor Pat McCrory in 2016, though notably, the legislature itself remains overwhelmingly dominated by the movement's conservative opponents. Barber has made clear that he rejects both the religious right and the religious left. His is not a partisan but rather a biblical movement. Last summer he reduced his obligations in North Carolina in order to focus on organizing a new "poor people's campaign" that he hopes will change the nation's "moral narrative." It will be an uphill fight.

We historians are not in the business of predicting what happens next. But this much seems clear: American Christians played pivotal roles in getting us into this New Gilded Age and we are in urgent need of a renewal of Christian economic thought and practices today if we are to have any hope of finding our way out.

\section{BIBLIOGRAPHY}

Addams, Jane. "The Subjective Necessity for Social Settlements." In Philanthropy and Social Progress. New York: Thomas Y. Crowell, 1893.

Bowler, Kate. Blessed: A History of the American Prosperity Gospel. New York: Oxford University Press, 2013.

Carter, Heath W. Union Made: Working People and the Rise of Social Christianity in Chicago. New York: Oxford University Press, 2015.

Chappell, David L. A Stone of Hope: Prophetic Religion and the Death of Jim Crow. Raleigh, NC: University of North Carolina Press, 2005. 
“Christianity a Failure." Workingman's Advocate 4, no. 42 (9 May 1868): 2.

Collins, Chuck, and Josh Hoxie. "Billionaire Bonanza: The Forbes 400 and the Rest of Us." Institute for Policy Studies, 2017. Available via https://ips-dc.org/wp-content/uploads/2017/11/BILLIONAIREBONANZA-2017-FinalV.pdf. Accessed 7 August 2018.

Creech, Joe. Righteous Indignation: Religion and the Populist Revolution. Urbana: University of Illinois Press, 2006.

Day, Dorothy. Loaves and Fishes: The Inspiring Story of the Catholic Worker Movement. New York: Orbis Books, 1997.

Dochuk, Darren. From Bible Belt to Sunbelt: Plain-Folk Religion, Grassroots Politics, and the Rise of Evangelical Conservatism. New York: W. W. Norton, 2011.

Dorrien, Gary. The New Abolition: W. E. B. Du Bois and the Black Social Gospel. New Haven: Yale University Press, 2015.

Dudziak, Mary L. Cold War Civil Rights: Race and the Image of American Democracy. Princeton: Princeton University Press, 2000.

Evans, Christopher H. The Kingdom Is Always but Coming: A Life of Walter Rauschenbusch. Grand Rapids: William B. Eerdmans Publishing Company, 2004.

Farber, Henry S., Daniel Herbst, Ilyana Kuziemko, and Suresh Naidu. "Unions and Inequality over the Twentieth Century: New Evidence from Survey Data." Working Paper. Available via https://dataspace.princeton.edu/jspui/ bitstream/88435/dsp0lgx4lmm54w/3/620.pdf. Accessed 8 August 2018.

Fitzgerald, Maureen. Habits of Compassion: Irish Catholic Nuns and the Origins of New York's Welfare System. Urbana: University of Illinois Press, 2006.

Gellman, Erik S., and Jarod Roll. The Gospel of the Working Class: Labor's Southern Prophets in New Deal America. Urbana: University of Illinois Press, 2011.

Hahn, Steven. A Nation Under Our Feet: Black Political Struggles in the Rural South from Slavery to the Great Migration. Boston: Harvard University Press, 2003.

Hendershot, Heather. Shaking the World for Jesus: Media and Conservative Evangelical Culture. Chicago: University of Chicago Press, 2004.

Hoy, Suellen. Good Hearts: Catholic Sisters in Chicago's Past. Urbana: University of Illinois Press, 2006.

Hunt, Bijou R., Gary Tran, and Steve Whitman. "Life Expectancy Varies in Local Communities in Chicago: Racial and Spatial Disparities and Correlates." Journal of Racial and Ethnic Health Disparities 2, no. 4 (December 2015): 425433.

Hutchison, William R. The Modernist Impulse in American Protestantism. Durham: Duke University Press, 1976.

Hyfler, Robert. Prophets of the Left: American Socialist Thought in the Twentieth Century. Westport, CT: Greenwood Press, 1984. 
"In Factory Girl Plea; Piecework is Scored." Chicago Record-Herald, 5 September 1910 .

Kazin, Michael. A Godly Hero: The Life of William Jennings Bryan. New York: Anchor Books, 2006.

Krugman, Paul. "Why We're in a New Gilded Age." The New York Times, May 8, 2014. Available via https://www.nybooks.com/articles/2014/05/ 08/thomas-piketty-new-gilded-age/. Accessed 7 August 2018.

Kruse, Kevin. One Nation Under God: How Corporate America Invented Christian America. New York: Basic Books, 2015.

Lassiter, Matthew D. The Silent Majority: Suburban Politics in the Sunbelt South. Princeton: Princeton University Press, 2006.

Lawrence Mishel, Elise Gould, and Josh Bivens, "Wage Stagnation in Nine Charts," Economic Policy Institute, 6 January 2015. Available via https://www.epi.org/files/2013/wage-stagnation-in-nine-charts.pdf. Accessed 7 August 2018.

Leon, Luis D. The Political Spirituality of Cesar Chavez: Crossing Religious Borders. Oakland: University of California Press, 2014.

“Liberal Christianity." Workingman's Advocate 4, no. 17 (16 November 1867): 2 .

Martin, George. Madam Secretary, Frances Perkins, vii. Boston: Houghton Mifflin Company, 1976.

Mishel, Lawrence, Elise Gould, and Josh Bivens. "Wage Stagnation in Nine Charts." Economic Policy Institute, January 6, 2015. Available via https://www.epi.org/files/2013/wage-stagnation-in-nine-charts.pdf. Accessed 7 August 2018).

Moore, R. Laurence. Selling God: American Religion in the Marketplace of Culture. New York: Oxford University Press, 1994.

Moreton, Bethany. To Serve God and Wal-Mart: The Making of Christian Free Enterprise. Boston: Harvard University Press, 2009.

"New Deal Is Based on Christ's Tenets, Ickes Says in Talk." Chicago Daily Tribune, 24 May 1934.

Noll, Mark A. The Civil War as a Theological Crisis. Chapel Hill: University of North Carolina Press, 2006.

Pehl, Matthew. The Making of Working-Class Religion. Urbana: University of Illinois Press, 2016.

Posner, Eric, and Glen Weyl. "The Real Villain Behind Our New Gilded Age." The New York Times, May 1, 2018. Available via https://www.nytimes.com/ 2018/05/01/opinion/monopoly-power-new-gilded-age.html. Accessed 7 August 2018.

Rauschenbusch, Walter. Christianity and the Social Crisis, xiii. New York: Macmillan, 1907.

“Rev. Dr. Westwood.” Workingman's Advocate 5, no. 27 (30 January 1869): 2. 
Sommeiller, Estelle, and Mark Price. "The New Gilded Age: Income Inequality in the U.S. by State, Metropolitan Area, and County." Economic Policy Institute, July 19, 2018. Available via https://www.epi.org/files/pdf/147963. pdf. Accessed 7 August 2018.

Stowe, David W. No Sympathy for the Devil: Christian Pop Music and the Transformation of American Evangelicalism. Raleigh: University of North Carolina Press, 2011.

Swing, David. "The Labor Turmoil." Alliance 1, no. 4 (3 January 1874): 2.

"Union Members Summary." Bureau of Labor Statistics, 19 January 2018. Available via https://www.bls.gov/news.release/pdf/union2.pdf. Accessed 7 August 2018.

Open Access This chapter is licensed under the terms of the Creative Commons Attribution 4.0 International License (http://creativecommons.org/licenses/ by $/ 4.0 /)$, which permits use, sharing, adaptation, distribution and reproduction in any medium or format, as long as you give appropriate credit to the original author(s) and the source, provide a link to the Creative Commons license and indicate if changes were made.

The images or other third party material in this chapter are included in the chapter's Creative Commons license, unless indicated otherwise in a credit line to the material. If material is not included in the chapter's Creative Commons license and your intended use is not permitted by statutory regulation or exceeds the permitted use, you will need to obtain permission directly from the copyright holder.

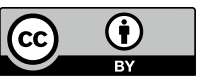

